\title{
Process optimization for the manufacture of red rice (Oryza sativa L.) kheer
}

\author{
Anjali Kumari and Amrita Poonia
}

Received: 14 April 2021 / Accepted: 30 August 2021 / Published online: 31 October 2021

(C) Indian Dairy Association (India) 2021

\begin{abstract}
Red rice contained $13.92 \pm 0.13 \%$ moisture, $2.11 \pm 0.07$ $\%$ fat, $1.80 \pm 0.01 \%$ total ash and $144.45 \pm 1.36(\mathrm{mgGAE} / 100 \mathrm{~g})$ total phenolic content, respectively. The present study was aimed to prepare kheer using red rice @ 18g $\left(\mathrm{T}_{1}\right), 20 \mathrm{~g}\left(\mathrm{~T}_{2}\right)$ and $22 \mathrm{~g}\left(\mathrm{~T}_{3}\right)$. Coconut sugar was used @15 g in all the combinations. Fresh toned milk (3.0\% fat and 8.5\% SNF) was used with broken red rice (Half broken) grains. Cleaned broken rice was soaked in water (rice to water ratio as $1: 2.5$ ) and cooked at $93^{\circ} \mathrm{C}$ for about 15 minutes. Kheer prepared using $20 \mathrm{~g}$ of rice (T2) was selected as optimized one on the basis of sensory evaluation. The developed red rice kheer was acceptable upto 10 days of storage at refrigerated temperature. Optimized kheer contained 3.02 $\pm 1.21 \%$ fat, $56.16 \pm 2.11 \%$ moisture and $43.84 \pm 3.05 \%$ total solids and $356.24 \pm 3.45$ Total Phenolic Content (mgGAE/100g)
\end{abstract}

Keywords: Red rice, Kheer, Coconut sugar, Shelf- life, Total phenolic content

\section{Introduction}

Kheer is very popular traditional dairy product consumed all over India. Kheer is considered as nutritious dairy dessert. But its production is limited to household level and unorganized sector only. Red rice is superior to white rice due to its nutritional

Department of Dairy Science and Food Technology, Institute of Agricultural Sciences, Banaras Hindu University, Varanasi, 221005, Uttar Pradesh, India

Amrita Poonia $(\square)$

Department of Dairy Science and Food Technology, Institute of Agricultural Sciences, Banaras Hindu University, Varanasi-221005, Uttar Pradesh, India

Email: amrita12@bhu.ac.in; dramritapoonia@gmail.com profile and health benefits. So, the use of red rice in place of white rice will not only offer opportunities to develop value added food products but also enhance the nutritional and functional properties of kheer.

Red rice is rich in antioxidant, minerals and protein as compared to white rice. Due to its lower glycemic index $(63.15 \pm 2.63 \mathrm{mg} / \mathrm{dl})$ than white rice, red rice can be a part of the diets of diabetics as well as persons suffering from other non-communicable diseases. Red rice is a storehouse of nutritional excellence and is a healthier alternative to white or polished rice (Raghuvanshi et al. 2017). Due to the high fibre content, red rice possesses the ability to keep healthy metabolic function and bowel function also. It can help in weight management due to anthocyanins. Red rice is highly useful in treating and controlling different ailments due to its nutritional value and its use is very common among the practitioners of traditional medicines and communities. (Rathna Priya et al. 2019).

Increasing threats of ailments such as obesity, hypertension and diabetes mellitus etc. has become a serious concern for the people suffering with such ailments due to the high intake of sugar in food and confectionary products. Production of sweeteners made naturally with low Glycemic Index (GI) can be a solution for such ailments. Only red rice as a main ingredient won't serve the purpose of preparing a healthy kheer, so coconut sugar was incorporated in the kheer because of its nutritional profile. Coconut sugar was reported to have glycemic index of about 35 (Kusumawaty et al. 2012). Foods with low glycemic index (GI) are important for diabetes, obesity, heart disease and hypertension (Jenkins et al. 1981). Coconut sugar is a good source of minerals like zinc, iron, calcium, phosphorous, potassium and magnesium. Hebbar et al. (2015) also reported that coconut sugar is good source of vitamins, such as vitamin C, B complex, antioxidants, polyphenols and dietary fibres. Now- a -days, coconut sugar becomes very popular among health conscious consumers. Milk is deficient in iron, vitamin C and other minerals are also found in less quantity. So far no work has been carried out on the utilization of red rice for preparation of traditional dairy products; hence this work has been planned for optimization a process for manufacture of kheer. Therefore, red rice, coconut 
sugar and milk will formulate a perfect, balanced and healthy combination for kheer.

\section{Materials and Methods}

Red rice of Truefarm and coconut sugar of Tropicoco Kokos Natural was purchased via online from Flipkart. Toned milk of Amul with 3.0\% fat and 8.5\% SNF was purchased from the local market of Varanasi.

\section{Proximate composition of red rice}

By following the method of AOAC (2000), moisture and fat content was calculated by taking $5 \mathrm{~g}$ of sample. The ash content of finely ground sample of red rice was estimated by following the protocol of (AOAC 2000). Total phenolic content was determined by using Folin Ciocalteau procedure of (Singleton and Rossi, 1965).

\section{Formulation of red rice $k h e e r$}

All the ingredients were mixed together in required quantities. Red rice was incorporated in three different quantities which were 18, 20 and 22g, respectively. Coconut sugar was incorporated (a) $15 \mathrm{~g}$. Fresh toned milk was used in constant quantity of $500 \mathrm{ml}$ in all the three treatments. Kheer prepared by adding white rice $12.5 \mathrm{~g}$ into $500 \mathrm{ml}$ of toned milk was taken as control. Notations for control and different treatments are shown below:

$\mathrm{T}_{0}=$ White rice $(12.5 \mathrm{~g})+\operatorname{Sugar}(25 \mathrm{~g})+$ Toned Milk $(500 \mathrm{ml})$ as control

$\mathrm{T}_{1}=\operatorname{Red}$ Rice $(18 \mathrm{~g})+$ Coconut Sugar $(15 \mathrm{~g})+$ Toned Milk $(500 \mathrm{ml})$

$\mathrm{T}_{2}=$ Red Rice $(20 \mathrm{~g})+$ Coconut Sugar $(15 \mathrm{~g})+$ Toned Milk $(500 \mathrm{ml})$

$\mathrm{T}_{3}=$ Red Rice $(22 \mathrm{~g})+$ Coconut Sugar $(15 \mathrm{~g})+$ Toned Milk $(500 \mathrm{ml})$

\section{Preparation of Kheer}

Initially, clean and dry red rice grains were broken (half) into a mixer grinder. Kheer was prepared by using the standard method (Kumar et al. 2005) with some modifications. Red rice was soaked in water at room temperature(rice: water as 1:2.5) for 30 minutes and precooked at $93^{\circ} \mathrm{C}$ for $10 \mathrm{~min}$. Precooked red rice was added to boiled toned milk ( $3 \%$ fat and $8.5 \% \mathrm{SNF}$ ) with continuous agitation of the mixture (Fig.1 \& Fig.2).

\section{Sensory evaluation of red rice $k$ heer}

Sensory evaluation of red rice kheer was done by panel of 20 semi -trained judges in respect of colour \& appearance, flavour, body $\&$ texture and overall acceptability. Score card was provided to all judges comprising 9 points Hedonic Scale.

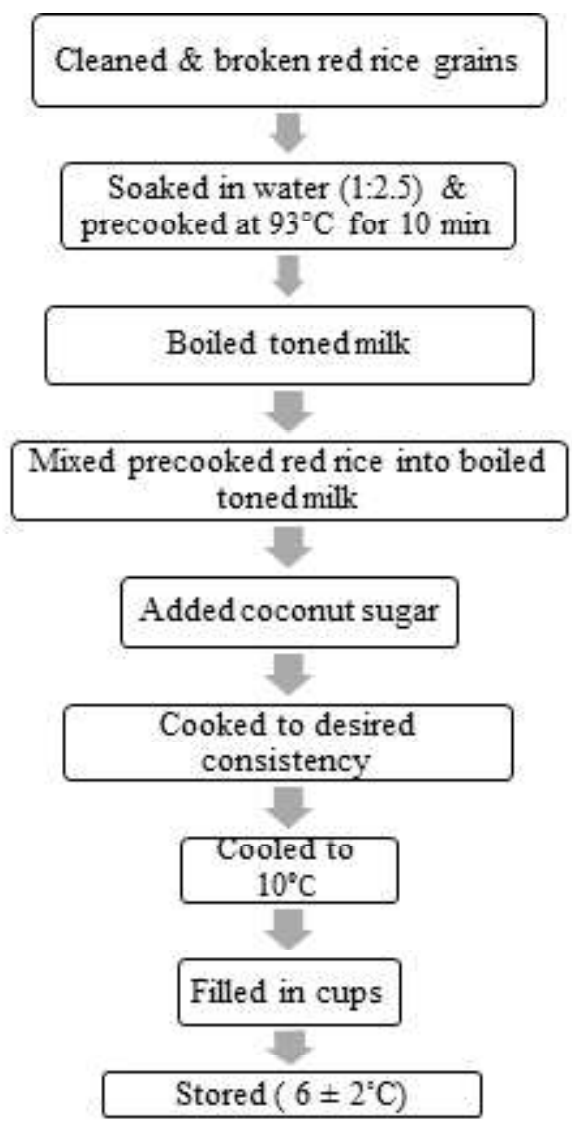

Fig.1 Flow diagram for preparation of red rice $k$ heer

\section{Chemical composition of red rice kheer}

By following the method of AOAC (2000), moisture content was calculated by taking $5 \mathrm{~g}$ of sample. After the determination of moisture, the left residue was taken for calculation the total solid content

Moisture content was calculated by the formula:-

Moisture $(\%)=(\mathrm{W} 2-\mathrm{W} 1) \times 100$

(W1-W)

Where,

$\mathrm{W}=$ Weight of empty dish

$\mathrm{W} 1=$ Weight of dish with the sample

$\mathrm{W} 2=$ Final weight of dish

\section{Statistical Analysis}




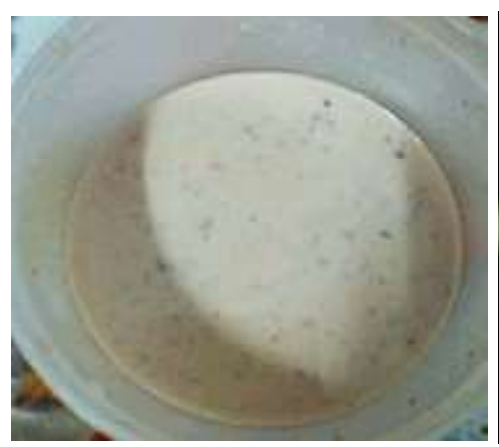

$\mathbf{T}^{1}$

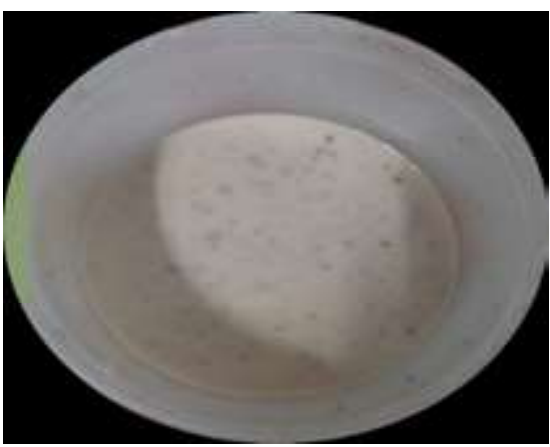

$T^{2}$

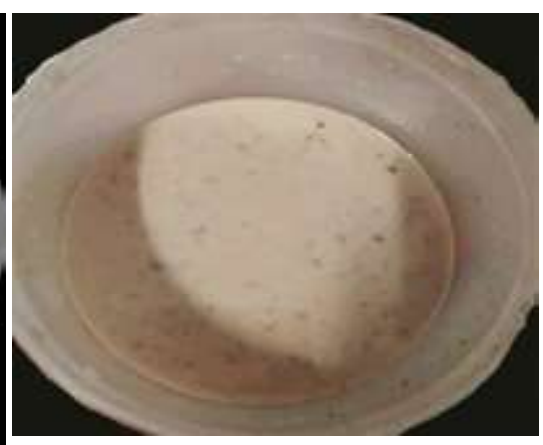

$\mathbf{T}^{3}$

Fig. 2 Different formulations of red rice kheer

Table1 Proximate composition and total phenolic content of red and white rice

\begin{tabular}{llc}
\hline Constituents & White Rice & Red Rice \\
\hline Moisture (\%) & $12.85 \pm 0.15$ & $13.92 \pm 0.13$ \\
Crude fat (\%) & $0.67 \pm 0.01$ & $2.11 \pm 0.07$ \\
Total Ash (\%) & $0.57 \pm 0.04$ & $1.80 \pm 0.01$ \\
Total Phenolic Content (mgGAE/100g) & $25.09 \pm 1.10$ & $144.45 \pm 1.36$ \\
\hline
\end{tabular}

Data represents as mean \pm Standard Deviation $(n=3)$ at $(p>0.05)$

The data obtained during the course of investigation were subjected to statistical analysis. One-way analysis of variance (ANOVA) was applied to analyze test of significance.

\section{Results and Discussion}

\section{Shelf- life of red rice $k h e e r$}

Based on the sensory characteristics of the different combinations T2 was selected for shelf- life study with control sample of white rice kheer. Kheer was packed in polystyrene cups of $100 \mathrm{~g}$ capacity and stored at $6 \pm 2{ }^{\circ} \mathrm{C}$ in refrigerator. The $\mathrm{pH}$, acidity and microbial parameters of red rice kheer were determined at an interval of 2 days for a period of 10 days

\section{Proximate composition of red rice}

The moisture and fat per cent content of red rice was $13.92 \pm 0.13$, $2.11 \pm 0.07$ which was on the higher side then the control i.e. 12.85 \pm 0.15 and $0.67 \pm 0.01$, respectively (Table 1 ). Similar results were reported by (Raghuvanshi et al. 2017). They found that red rice have $12.75 \%$ moisture, $1.53 \%$ ash and $1.81 \%$ fat. The ash content of red rice was also higher than white rice as red rice is highly rich in fibre as compared to wheat and many other vegetables. (Gopalan et al. 2007). The total phenolic content of red rice was $144.45 \pm 1.36 \mathrm{mg}$ catechin equivalent/g observed higher than that of white rice $25.09 \pm 1.10 \mathrm{mg}$ catechin $/ \mathrm{g}$. Sompong et al. (2011) estimated the total phenolic content of total ten different red rice varieties ranging between 79.2 and $691.4 \mathrm{mg}$ FA equivalent $/ 100 \mathrm{~g}$. The total phenolic content and total flavonoids content of red rice was found to be $143.38 \mathrm{mg} \mathrm{GAE} / 100 \mathrm{gm}$ and 120 mg R.E. /100 gm respectively (Raghuvanshi et al. 2017).

\section{Sensory analysis}

Table 2 depicts that the sensory score for body and texture of $\mathrm{T}_{2}$ formulation was found to score highest i.e. $8.50 \pm 0.24$ which was found to be statistically non-significant over other treatments at $(\mathrm{P}>0.05)$. The sensory score for overall acceptability of $\mathrm{T}_{2}$ formulation was highest $8.11 \pm 0.19$ which was found to be statistically non-significant over other treatments at $(\mathrm{P}>0.05)$. Therefore, $\mathrm{T}_{2}$ was the optimized product on the basis of sensory evaluation. Addition of more than $20 \mathrm{~g}$ of red rice in kheer resulted in highly viscous product which results in poor score. Similar results were observed by Sandey et al. (2009). They found that flavour score of cereal based dairy product prepared with $10 \%$ and $20 \%$ of little millet flour were statistically at par and product with $10 \%$ addition of little millet resulted in smooth and soft body and texture.

\section{Chemical composition of red rice kheer}

Optimised red rice-based kheer has total solids content of $43.84 \pm$ 3.0, whereas the total solids per cent of control was $44.57 \pm 2.78$. Similar results were reported by (Mor et al. 2017). The optimised product has the higher total solid content than that of control which was significantly not different from each other (Table 3 ). The statistical data shows non-significant difference between values ( $p>0.05)$. Deshmukh et al. (2017) estimated the total solid content of poppy seeds kheer which was observed as $41.42 \%$.

Coconut sugar also influenced the free radical capacity significantly $(\mathrm{P}<0.05)$. Low et al. (2015) studied the antioxidant activity of probiotic ice cream by incorporating different levels of cane sugar and coconut palm sugar. Total phenolic content of 
Table 2 Sensory evaluation of red rice kheer

\begin{tabular}{lllll}
\hline Treatments & $\begin{array}{l}\text { Body and } \\
\text { Texture }\end{array}$ & $\begin{array}{l}\text { Colour and } \\
\text { appearance }\end{array}$ & Flavour & $\begin{array}{l}\text { Overall } \\
\text { acceptability }\end{array}$ \\
\hline T0 & $7.50 \pm 0.31$ & $7.00 \pm 0.23$ & $8.50 \pm 0.17$ & $7.66 \pm 0.23$ \\
T1 & $7.50 \pm 0.26$ & $7.50 \pm 0.29$ & $7.50 \pm 0.14$ & $7.50 \pm 0.24$ \\
T2 & $8.50 \pm 0.24$ & $7.83 \pm 0.18$ & $8.00 \pm 0.16$ & $8.11 \pm 0.19$ \\
T3 & $6.88 \pm 0.31$ & $7.25 \pm 0.25$ & $7.00 \pm 0.26$ & $7.04 \pm 0.27$ \\
\hline
\end{tabular}

Values are mean \pm Standard Deviation $(n=20)$

Table 3 Chemical composition of optimized red rice kheer

\begin{tabular}{lll}
\hline Constituents & Control $\left(\mathrm{T}^{0}\right)$ & Optimised $\left(\mathrm{T}^{2}\right)$ \\
\hline Fat $(\%)$ & $2.45 \pm 0.89$ & $3.82 \pm 1.21$ \\
Moisture (\%) & $55.43 \pm 2.88$ & $56.16 \pm 2.11$ \\
Total Solids (\%) & $44.57 \pm 2.78$ & $43.84 \pm 3.05$ \\
Total Phenolic Content & $28.21 \pm 1.08$ & $356.24 \pm 3.45$ \\
(mgGAE/100g) & & \\
\hline
\end{tabular}

Data represented as mean \pm Standard Deviation $(n=3)$ at $(\mathrm{p}>0.05)$

Table 4 Changes in $\mathrm{pH}$, acidity and microbial count of red rice kheer during storage

\begin{tabular}{llll}
\hline $\begin{array}{l}\text { Storage } \\
\text { duration(days) }\end{array}$ & Acidity $(\%)$ & SPC $(\log$ CFU/g) \\
\hline 0 & Control : $6.34 \pm 0.40$ & Control : $0.34 \pm 0.01$ & Control : Nil \\
& Optimized: $6.40 \pm 0.60$ & Optimized: $0.21 \pm 0.03$ & Optimized: Nil \\
2 & Control : $6.30 \pm 0.42$ & Control : $0.36 \pm 0.03$ & Control : $1.08 \pm 0.40$ \\
& Optimized: $6.37 \pm 0.53$ & Optimized: $0.22 \pm 0.10$ & Optimized: $1.02 \pm 0.20$ \\
4 & Control: $6.23 \pm 0.72$ & Control : $0.40 \pm 0.12$ & Control : $2.45 \pm 0.12$ \\
& Optimized: $6.32 \pm 1.01$ & Optimized: $0.21 \pm 0.40$ & Optimized: $2.32 \pm 0.42$ \\
6 & Control: $6.24 \pm 0.71$ & Control : $0.45 \pm 0.03$ & Control : $3.40 \pm 0.22$ \\
& Optimized: $6.27 \pm 0.50$ & Optimized: $0.20 \pm 0.08$ & Optimized: $3.53 \pm 0.23$ \\
8 & Control: $6.20 \pm 0.22$ & Control : $0.50 \pm 0.06$ & Control : $4.35 \pm 0.21$ \\
& Optimized: $6.24 \pm 1.01$ & Optimized: $0.22 \pm 0.20$ & Optimized: $6.12 \pm 0.20$ \\
10 & Control : $6.10 \pm 0.64$ & Control : $0.54 \pm 0.05$ & Control : $4.90 \pm 0.31$ \\
& Optimized: $6.20 \pm 0.65$ & Optimized: $0.21 \pm 0.31$ & Optimized: $4.42 \pm 0.45$ \\
\hline
\end{tabular}

Values mentioned as mean \pm Standard Deviation, $(n=3)$ at $(\mathrm{p}>0.05)$

optimized kheer was significantly higher $(\mathrm{P}<0.05)$ as compared to control kheer i.e. $58.21 \pm 1.08$ and $356.24 \pm 3.45 \mathrm{mgGAE} / 100 \mathrm{~g}$, respectively. Mudoi and Das (2019) analyzed sixteen varieties of red rice for various phytochemicals, antioxidant activities and a few mineral contents. They reported that the antioxidant activities were observed to be the highest $96.00 \pm 0.26 \%$ in 'Negheribao' (for brown form of rice)and $86.35 \pm 3.88 \%$ in 'Kenekuabao' (for polished form of rice) and the lowest $81.54 \pm 0.23 \%$ in 'Betu'(for brown form of rice) and 59.65 $\pm 4.64 \%$ in 'Ranga Dariya' (polished rice), respectively. Red rice as well as coconut sugar has influenced the phenolic content of kheer. Similar results have been reported by Victor and Orsat (2018) who studied that palm sugar has appreciable amount of antioxidant activity and total phenolic content also.

\section{Shelf- life of red rice kheer}

During storage, the $\mathrm{pH}$ of red rice $k$ heer was decreased and acidity was increased significantly $(\mathrm{P}<0.05)$ and their interaction effect was found non-significant on $\mathrm{pH}$ and acidity of product (Table 4). Similar results were reported by (More et al. 2017). They reported that during storage, little millet kheer at refrigerated temperature $\left(6 \pm 1^{\circ} \mathrm{C}\right)$ the $\mathrm{pH}$ decreased significantly while acidity and viscosity increased. Standard plate count (SPC) count of kheer was increased significantly during storage. Yeast \& mould count and coliform count was found nil during the storage period.

\section{Economic Analysis}

To assess and evaluate the overall impact of a project in monetary and quantifiable terms, cost analysis of red rice kheer was done by taking all the used ingredients into consideration. In order to determine the feasibility of the study, cost of production was calculated for optimized kheer (Table 5). Cost of raw materials was added along with packaging cost and marketing and distribution expenses. $100 \mathrm{~g}$ (one cup) of red rice kheer was prepared in approximately Rs. 15.16 . The profit margin at $25 \%$ of 
Table 5 Cost analysis of red rice kheer $(100 \mathrm{~g})$

\begin{tabular}{lll}
\hline Ingredients & Quantity & Cost (Rs.) \\
\hline Red rice & $20 \mathrm{~g}$ & 4.0 \\
Coconut Sugar & $15 \mathrm{~g}$ & 13.5 \\
Toned Milk & $500 \mathrm{ml}$ & 22.0 \\
Total (Quantity of kheer) & $300 \mathrm{~g}$ & 39.5 \\
& Quantity/100g/cup & 13.16 \\
Packaging cost & 1 cup + Aluminium foil & 1.0 \\
& Total & 14.16 \\
Processing cost & Per cup & 1.0 \\
& Total & 15.16 \\
Marketing and distribution expenses @ $25 \%$ of product & Per cup (100g) & 3.29 \\
& Total & Rs. 18.45 \\
\hline
\end{tabular}

cost of product is also applied which took overall price of kheer to a very nominal price of Rs. 18.45 .

\section{Conclusion}

Kheer is consumed by wide group of population. In the present study, red rice kheer with coconut sugar as a natural sweetener was prepared which has higher amount of protein, fiber, minerals as compare to white rice. It can be concluded that the treatment $\mathrm{T}_{2}$ of red rice kheer prepared by mixing $20 \mathrm{~g}$ of red rice and $15 \mathrm{~g}$ of coconut sugar with $500 \mathrm{ml}$ of toned milk ( $3 \%$ fat and $8.5 \% \mathrm{SNF}$ ) was found to be the most acceptable. Both red rice and coconut sugar has low glycemic index which is good for the consumers suffering from diabetes. This product was prepared with the aim to provide nutrition to consumers of every age group.

\section{Acknowledgements}

Sincere thanks are extended to Institutions of Eminence (IoE) scheme, Banaras Hindu University, Varanasi (U.P) India, for financial support under Incentive to Senior Faculties under IoE.

\section{References}

AOAC (2000) Official Methods of Analysis of the Association of Official Analytical Chemists. 17th ed. Washington D.C., U.S.A.

Deshmukh SV, Ingole AS, Atkare VG, Khupse SM, Akhud MW (2017) Studies on preparation of poppy seeds (Papaver somiferum) kheer from cow milk. J Soils and Crops 27: 87-91

Gopalan C, Rama Sastri BV and Balasubramaniam SC (2007) Nutritive Value of Indian Foods. National Institute of Nutrition. Indian Council of Medical Research, Hyderabad.

Hebbar KB, Arivalagan M, Manikantan MR, Mathew AC, Thamban C, Thomas GV, Chowdappa P (2015) Coconut inflorescence sap and its value addition as sugar-collection techniques, yield, properties and market perspective. Curr Sci 109: 1411-141710.18520/cs/v109/ i8/1411-1417

Jenkins DJA, Wolever TMS, Taylor RH (1981) Glycemic index of foods: A physiological basis for carbohydrate exchange. Am J Clin Nutr 34: 362-366

Kumar AJ, Singh RRB, Patil GR and Patel AA (2005) Effect of temperature on moisture desorption isotherms of kheer. LWT- Food Sci Technol 38: $303-310$
Kusumawaty Y, Maharani E, Edwina S (2012) Perceived quality of coconut sugar by producers, traders and downstream industries in Indragiri Hilir District, Riau Province, Indonesia. J Agribusiness Marketing 5: $1-13$

Low RHP, Baba AS, Aboulfazli F (2015) Effects of different levels of refined cane sugar and unrefined coconut palm sugar on the survivability of Lactobacillus acidophilus in probiotic ice cream and its sensory and antioxidant properties. Food Sci Technol Res 21: 857-862.

Mor C, Dharaiya CN, Pinto SV, Prajapati JP (2017) Replacement of rice with little millet in kheer. Indian J Dairy Sci 70:513-518

Mudoi T and Das P (2019) A Study on Phytochemicals and Mineral Content of Indigenous Red Rice of Assam, India Int J Curr Microbiol App Sci 8:1-12 DOI: https://doi.org/10.20546/ijcmas.2019.804.001

Raghuvanshi RS, Dutta A, Tewari G, Suri S (2017) Qualitative Characteristics of Red Rice and White Rice Procured from Local Market of Uttarakhand: A Comparative Study. J Rice Res 10:49-53

Rathna Priya T, Eliazer Nelson ARL, Ravichandran K, Antony U (2019) Nutritional and functional properties of coloured rice varieties of South India: a review. J. Ethn Food 6-11 https://doi.org/10.1186/ s42779-019-0017-3

Sandey KK, Asgar S, Manorama,Choudhary PL (2009) Utilization of little millet flour for preparation of dairy product. Res J Sci Techno1 1: $71-73$

Singleton VL, Orthofer R and Lamuela-Raventos RM. (1999) Analysis of total phenols and other oxidation substrates and antioxidants by means of FolinCiocalteu reagent. Methods Enzymol. 299:152-178.

Sompong R, Siebenhandi ES, Linsberger MG, Berghofer E (2011) Physicochemical and antioxidative properties of red and black rice varieties from Thailand, China and Sri Lanka. Food Chem 124: 132-140.

Victor I, Orsat V (2018) Characterization of Arengapinnata (palm) sugar. Sugar Technol 20: 105-109 